\title{
Overview of the Implementation of Health Care Education in Diabetes Mellitus Patients with Diet Nonconformity
}

\author{
$1^{\text {st }}$ Gunardi Pome \\ Nursing Department \\ Poltekkes Kemenkes Palembang \\ Palembang, Indonesia \\ gunardi.pome@yahoo.com
}

\author{
$2^{\text {nd }}$ Ira Kusumawaty \\ Nursing Department \\ Poltekkes Kemenkes Palembang \\ Palembang, Indonesia \\ Irakusumawaty@poltekkespalembang.ac.id yunike@poltekkespalembang.ac.id
}

\author{
$3^{\text {rd }}$ Yunike \\ Nursing Department \\ Poltekkes Kemenkes Palembang \\ Pal Kementes Palemba \\ $4^{\text {th }}$ Lili Resta Septiana \\ Nursing Department \\ Poltekkes Kemenkes palembang \\ Palembang, Indonesia \\ lilirestawr@gmail.com
}

Corresponding author: yunike@ poltekkespalembang.ac.id

\begin{abstract}
Diabetes mellitus is a disease caused by declining levels of insulin that is characterized by increased blood sugar levels that can cause some chronic diseases in some organs of the body. The problem in this case study is the non-compliance diet in diabetes mellitus type 2 patients. Non-compliance diet is the behavior of a person who does not follow the recommended diet by a physician or other health worker who can cause treatment results is not to be ineffective. This research aims to get an overview of the implementation of nursing health education in Diabetes mellitus type II patients with dieting problems. This method type of research is narrative in the form of literature studies. The article criteria/research results used in this study consist of 6 (six) articles/research results published online between 2015-2019. The articles/results of such studies are available in full text for researchers to use as data for analysis. The result this research is based on the results of previous research obtained and articles as a reference to literature study there is a way to reduce the problem of dietary disobedience in patients with type II of DM, one of them using the implementation of health education nursing. Health education is needed because DM disease is a lifestyle-related disease that needs an increase in knowledge to change lifestyles. Therefore, it is gained that knowledge is very influential about the diet adherence to DM patients type II and health education is the proper implementation to solve the problem.

Keywords: health education, DM diet, non-compliance DM diet, blood sugar, type II of DM.
\end{abstract}

\section{INTRODUCTION}

Diabetes mellitus is a disease caused by a decrease in the amount of insulin from the pancreas which causes metabolic disorders that occur in the pancreas which is characterized by an increase in blood sugar or often referred to as hyperglycemia [1]. Currently the number of people with diabetes mellitus in the world is increasing [2]. The number of people with diabetes mellitus is 422 million adults who are over 18 years old. The International of Diabetic Federation (IDF) revealed that in 2015 the number of people with diabetes mellitus in the world was 415 million people and it is estimated that in 2040 it will increase to 642 million people. Meanwhile, based on data from the International Diabetes Federation [3], Indonesia is ranked seventh in the world along with China, India, the United States, Brazil, Russia and Mexico with an estimated number of people with diabetes of 10 million. The population of people with diabetes in Indonesia who have been diagnosed with diabetes by a doctor reaches 2.6 million people. Data from Riskesdas 2013 stated that the number of diabetes sufferers in South Sumatra reached 49 thousand people who had been diagnosed by a doctor. Type II diabetes is the type that dominates of all diabetics, as much as $90 \%$ are type II diabetes sufferers [4].

Diabetes mellitus type II can cause several complications that vary including physical, psychological, social and economic complications. Physical complications that arise include eye damage, kidney damage, heart disease, high blood pressure, stroke and even gangrene [5]. Some of the causes of diabetes are heredity, age, gender, obesity, infection of 
the pancreas gland, lack of physical activity such as exercise and irregular eating patterns. Several ways to prevent diabetes mellitus can be done by changing life patterns such as adjusting diet and habits and providing knowledge about diabetes to people with diabetes mellitus [6]. Diet aims to help people with Type 2 Diabetes Mellitus improve their eating habits so they can control glucose, fat and blood pressure levels. In Indonesia, non-compliance is one of the causes of complications, this is evidenced by the results of research conducted [7], namely that there is a relationship between the patient's dietary compliance level with the emergence of complications at the Puskesmas Pesantren II, Kediri city in 2010. Therefore, researchers feel the need there is an increase in counseling by health workers about the importance of adhering to the diet in diabetes mellitus patients properly so that complications do not arise.

\section{METHOD}

This type of research is narrative in the form of literature studies. The article criteria/research results used in this study consist of 6 (six) articles/research results published online between 2015-2019. The articles/results of such studies are available in full text for researchers to use as data for analysis. The articles and research results used in this study were obtained through exploration of the Google Scholar source for 6 articles. Research data analysis was carried out by researchers by presenting 6 research articles that have relevance to the topic or research problem. The next

\begin{tabular}{|c|c|c|c|c|}
\hline $\begin{array}{c}\text { Researcher and Research } \\
\text { Title }\end{array}$ & Research Pusposes & Design & Sample & Results \\
\hline $\begin{array}{l}\text { Insiyah, Rini Tri } \\
\text { Hastuti } \\
(2016) \\
\text { Level of Knowledge and } \\
\text { Compliance About } \\
\text { Diabetes Mellitus Diits in } \\
\text { Diabetes Mellitus Patients } \\
\text { at Sibela Public Health } \\
\text { Center, Surakarta City }\end{array}$ & $\begin{array}{l}\text { The purpose of this } \\
\text { study was to determine } \\
\text { the characteristics of } \\
\text { Diabetes Mellitus } \\
\text { patients, to describe } \\
\text { the level of knowledge } \\
\text { and adherence to } \\
\text { diabetes diabetes } \\
\text { mellitus patients at the } \\
\text { Sibela Public Health } \\
\text { Center, Surakarta City. }\end{array}$ & $\begin{array}{l}\text { This research is a qualitative } \\
\text { descriptive study, which } \\
\text { describes the level of } \\
\text { knowledge and adherence to } \\
\text { diabetes mellitus patients at } \\
\text { the Sibela Public Health } \\
\text { Center in Surakarta with the } \\
\text { technique triangulation } \\
\text { method, namely observation } \\
\text { and interviews and } \\
\text { triangulation of data sources } \\
\text { from patients, health center } \\
\text { officers, and families. }\end{array}$ & $\begin{array}{l}\text { The sample } \\
\text { selection method } \\
\text { was purposive and } \\
\text { snowball sampling, } \\
\text { health center } \\
\text { officers, and } \\
\text { families. }\end{array}$ & $\begin{array}{l}\text { The results showed that the level of } \\
\text { knowledge and compliance with } \\
\text { diabetes mellitus in patients with } \\
\text { diabetes mellitus at the Sibela Public } \\
\text { Health Center in Surakarta was still } \\
\text { very diverse, the patient had } \\
\text { incomplete knowledge of DM. } \\
\text { Patients already know about the signs } \\
\text { and symptoms, causes, management } \\
\text { and complications but do not know } \\
\text { the number of minutes and do not } \\
\text { plan the diet. Adherence to the } \\
\text { patient's diet was still low with the } \\
\text { largest source of food consumption } \\
\text { from carbohydrates }>65 \% \text {. }\end{array}$ \\
\hline $\begin{array}{l}\text { Khoirun Nisa, Yesi } \\
\text { Hasneli, Rismadefi } \\
\text { Wofers, } 2017 . \\
\text { The Effectiveness of The } \\
\text { Health Belief Model } \\
\text { Against Knowledge About } \\
\text { DM-Disc Diet } \\
\text { Management. }\end{array}$ & $\begin{array}{l}\text { Knowing the } \\
\text { effectiveness of health } \\
\text { education based on the } \\
\text { health belief model on } \\
\text { knowledge about DM- } \\
\text { disc diet management. }\end{array}$ & $\begin{array}{l}\text { Quasy experimental } \\
\text { research design with non } \\
\text { equivalent control group } \\
\text { research design. }\end{array}$ & $\begin{array}{l}\text { The number of } \\
\text { samples in this } \\
\text { study were } 34 \\
\text { people who were } \\
\text { taken using } \\
\text { sampling with due } \\
\text { regard to the } \\
\text { inclusion criteria. }\end{array}$ & $\begin{array}{l}\text { The knowledge value of the } \\
\text { experimental group using the } \\
\text { Dependent } \mathrm{t} \text { test was obtained p value } \\
0.000<\mathrm{a}(0.05) \text {, it can be concluded } \\
\text { that there was an increase in } \\
\text { knowledge about diet management at } \\
\text { DM disc before and after being given } \\
\text { health education based on the health } \\
\text { belief model in the experimental } \\
\text { group. }\end{array}$ \\
\hline
\end{tabular}

step is the researcher analyzes the article by integrating research results, connecting related topics, identifying the main issues / research results relevant to the research study

\section{RESULTS}

The results of the study / article found that noncompliance could be caused by limited knowledge due to lack of information and limited patient education and low motivation. So it is highly recommended to implement health education about the $\mathrm{dm}$ diet. Then the results of other studies suggest and prove that the implementation of nursing, namely conducting health education can reduce the problem of dietary noncompliance in patients with type 2 diabetes mellitus. The implementation of health education to reduce the problem of diet non-compliance which is the topic of discussion in this study has relevance to a number of studies presented in the table. Health education can be done using the health belief model method, then the expository method, then using the educational method and can use the video method, the lecture method and can also use the DM-disc as a medium. Dietary adherence to DM was described by controlled blood sugar, using DM-specific sugars; breakfast; afternoon and evening with the appropriate schedule, quantity, and type. Then, the article review / research results used as data in this literature study are described in the following literature review table. 


\begin{tabular}{lll}
\hline Dyah Restuning 2015. & Knowing the effect of & This research method used a \\
Effectiveness of Diabetes & diabetes education on & quasi experimental design \\
Education in Increasing & dietary compliance in & pre-post test without control \\
Compliance with Diet & type 2 diabetes & group design. \\
Regulations in Type 2 & mellitus. & \\
Diabetes Mellitus & &
\end{tabular}

Diabetes Mellitus

The number of
samples was 82
respondents ( 41 for
the intervention
group and 41 for
the control group).

the control group).
The results of the study with the Wicoxon test in the intervention group obtained significant values $(\mathrm{p}=$ $0.002)$, there were differences in dietary compliance before and after being given diabetes education. The Mann Whitney difference test obtained a significant value $(\mathrm{p}=$ 0.020). There was a difference in dietary compliance before and after being given diabetes education between the intervention group and the control group.

Thatit Nurmawati, Yeni
Kartika Sari, Mitria
Setyaningsih, 2018.
The effectiveness of Health
Education with the
Expository method of
Meal Planning on the diet
of type 2 DM patients.

Knowing the effect of
expository method
health education on
meal planning on the
diet of people with
type 2 diabetes

This study used a quasy experimental design with a non-equivocal control group design

he sampling technique used in this study was purposive sampling. The sample was divided into the treatment group and the control group with 20 people each for collecting data.
Suryatun Haryono, Eros Siti Suryati, Raden Siti Maryam, 2018. (Health education about diet on diabetes patient compliance.)

The research sample in each intervention group and control group was 37 respondents. The sampling technique was using cluster random sampling.

\begin{tabular}{ll}
\hline Tri Susilaningsih, 2017. & $\begin{array}{l}\text { Knowing the effect of } \\
\text { The Effect of Health }\end{array}$ \\
$\begin{array}{l}\text { Education with Video } \\
\text { Media on the Level of Diet }\end{array}$ & $\begin{array}{l}\text { video media on the } \\
\text { level of dietary }\end{array}$ \\
Compliance in Diabetes & compliance in diabetes \\
Mellitus Patients in & mellitus sufferers at \\
Gamping 1 Public Health & Gamping 1 Public \\
Center Sleman & Health Center Sleman \\
Yogyakarta. & Yogyakarta.
\end{tabular}

\author{
The results showed that there was a \\ significant effect of health education \\ on increasing knowledge about diet, \\ blood sugar levels at time, increasing \\ dietary adherence to DM patients \\ before and after the intervention in \\ the control group $(\mathrm{p}=0.000)$.

The results showed that there was an
effect of providing health education
on adherence to posttet diet in the
intervention group and control group
as indicated by a p value of 0.016 .
The p value of the video media test
on the level of dietary compliance in \\ diabetes mellitus sufferers.
}

\section{DISCUSSION}

The discussion of this study is focused on the results of research from five (6) articles which found that the implementation of health education can improve dietary adherence and reduce dietary non-compliance in people with diabetes mellitus. From the discussion of the 6 (six) articles above, the researcher took 1 (one) review journal regarding the description of knowledge and non-compliance and 5 (five) of them regarding the effect of health education. One of the reviewed journals above suggests that patient non-compliance with diabetes mellitus diabetes is possible because of limited knowledge due to lack of information and limited patient education and low motivation. Evidenced by the patient's diet settings that are still not in accordance with the DM dietary provisions. Therefore, it is very important to conduct health education about diabetes mellitus in DM patients to reduce the complication rate
[8]. According [9] non-compliance is shown through behavior such as not obeying the recommendation to consume special sugar for DM sufferers; breakfast, lunch and evening are still large portions or do not comply with the $3 \mathrm{~J}$ rules (schedule, quantity, and type). Non-compliance is also considered to be one of the obstacles in achieving treatment goals, even though dietary non-compliance in DM is one of the risk factors that aggravate the body's metabolic disorders so that it can cause uncontrolled blood sugar levels which can then have an impact on the survival of DM patients.

Then, because in the first journal, it was stated that knowledge plays a very important role in the level of dietary adherence, the researchers took 5 (five) review journals on the effect of health education on diabetes mellitus on type 2 diabetes mellitus sufferers. and health education methods. The second article uses the theory model The health belief model where this theory 
is used to explain and predict health preventive behavior, as well as the role of illness and disease behavior. This model consists of four main constructs that affect health behavior, namely perceived susceptibility, which is a person's subjective perception of the risk of contracting a disease or disease, perceived severity is a person's opinion about the seriousness of the disease condition and the consequences, the perceived benefits ( perceived benefits) is the patient's belief in the effect of the recommended action to reduce the risk or seriousness of the impact, the perceived barriers are a person's feelings on the obstacles experienced during the recommended health measures [10]. In the second article also uses the DM-Disc diet model where the DM disc is a guideline in determining food and drink menus that have been measured and can be consumed by DM sufferers[11]. Then the third article [12] and the fifth article [9] used the usual health education method, namely the lecture method.[12] Diabetes education in the form of lectures can increase diabetes patient compliance. The more often a person gets counseling, the better his behavior will be. Then the third article [13] said the method with counseling often made it difficult for patients to implement the results of health education at home, which is why this researcher combined the lecture, discussion and assignment methods, this method is called the expository method. But even though there are differences in the way of delivery and health education methods, the results of the research to the 5 articles above are the same, from the 5 (five) articles above it was found that the implementation of health education about the DM diet can be done to overcome the problem of diet noncompliance in people with type 2 diabetes The results of the 5 (five) articles above support previous research conducted by research conducted [14] which states that one of the factors affecting dietary adherence in people with type 2 diabetes mellitus is knowledge. The lack of knowledge and the low information they get can lead to low dietary adherence in people with diabetes mellitus.States that there is a relationship between dietary behavior and blood sugar levels, where if food consumption behavior is not controlled or poor dietary behavior will result in high blood sugar levels and facilitate various complications. That is why health education about the DM diet must be carried out frequently because with frequent exposure to knowledge of the diet it can increase knowledge of the diabetes diet, so that it can affect the dietary compliance of diabetic patients. The more often a person gets counseling, the better his behavior will be. So that it can be concluded from the 5 (five) articles that discuss the effect of health education on the type 2
DM diet proves that the implementation of health education about the DM diet can be done to overcome the problem of diet non-compliance in people with type 2 diabetes.

\section{CONCLUSION}

So from the 6 (six) above, it can be concluded that knowledge is very influential on the dietary problems of type II patients and health education is the right implementation to solve this problem. It is gained that knowledge is very influential about the diet adherence to DM patients type II and health education is the proper implementation to solve the problem.

\section{ACKNOWLEDGMENT}

The author is grateful to the instituteof Research and Community services at Poltekkes Ministry of Health Palembang for given research opportunities.

\section{REFERENCES}

[1] (ADA) ADA. Medical advice for people with diabetes in emergency situations.American Diabetes Association Journal 2012.

[2] KEMENKES RI. Hari Diabetes Sedunia Tahun 2018. Pus Data Dan Inf Kementrian Kesehat RI 2019:1-8

[3] Beckman J. Global E\&P. vol. 72. 2012.

[4] Riskesdas. Infodatin-Diabetes. 2013.

[5] Yahya N. Hidup Sehat dengan Diabetes. 2018.

[6] Risnasari N. Hubungan Tingkat Kepatuhan Diet Pasien Diabetes Mellitus dengan Munculnya Komplikasi di Puskesmes Pesantren IIKota Kediri. Efektor 2014;01:15-9.

[7] Insiyah I, Hastuti RT. Tingkat Pengetahuan Dan Kepatuhan Tentang DIIT Diabetes Mellitus Pada Pasien Diabetes Mellitus Di Puskesmas Sibela Kota Surakarta. Interes J Ilmu Kesehat 2016;5:14-21. https://doi.org/10.37341/interest.v5i1.8.

[8] Haryono S, Suryati ES, Maryam RS. Pendidikan Kesehatan Tentang Diet Terhadap Kepatuhan Pasien Diabetes Mellitus. J Ris Kesehat 2018;7:91. https://doi.org/10.31983/jrk.v7i2.3308.

[9] Bayat F, Shojaeezadeh D, s M, Heshmat R, Baikpour M, Hosseini M. The effects of education based on extended health belief model in type 2 diabetic patients: A randomized controlled trial. J Diabetes Metab Disord 2013;12:1-6. https://doi.org/10.1186/2251-6581-12-45.

[10] Sarwono Waspadji. Penatalaksanaan Diabetes Melitus Terpadu 2009;15:37-41.

[11] Gripp KW, Ennis S, Napoli J. Exome Analysis in Clinical Practice: Expanding the Phenotype of Bartsocas-Papas Syndrome. Am J Med Genet Part A 
2013;161:1058-63.

https://doi.org/10.1002/ajmg.a.35913.

[12] Nurmawati T, Sari YK, Setyaningsih M. Efektifitas Pendidikan Kesehatan dengan Metode Ekspositori tentang 2018:257-62. https://doi.org/10.26699/jnk.v5i3.ART.p257.

[13] Nisa K, Hasneli Y, Woferst R. Efektifitas The Health Belief Model Terhadap Pengetahuan Tentang Manajemen Diet Dm-Disc Komplikasi ( American Diabetes Association Menurut Penelitian
Palanimuthu ( 2010 ) “ Tingkat Pengetahuan Diet Pasien Diabetes Mellitus Serta Komplikasinya Di Poli Endo 2017;8.

[14] Susilaningsih T. Pengaruh Pendidikan Kesehatan Dengan Media Video Terhadap Tingkat Kepatuhan Diet Pada Penderita Diabetes Mellitus Di Puskesmas Naskah Publikasi Disusun Oleh : Penderita Diabetes Mellitus Di Puskesmas. Ilmu Kesehat 2017:1-12. 